\title{
When culture clashes with individual human rights: A practical theological reflection on the dignity of widows

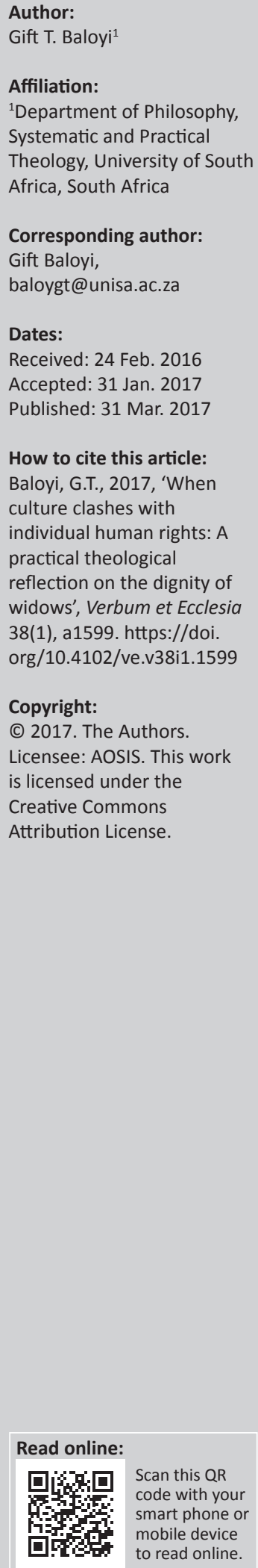

This article discusses the nature of human beings (men and women) as an egalitarian one even beyond cultural expectations. It argues against some cultural practices on women, especially widows, which claim supremacy and bind the widows to its ritual processes among the Tsonga people. It stresses the importance of human individual that overtakes everything from God's creation, including cultural rituals which are created by human beings. It claims that the existence of culture depends solely on the existence or presence of human beings and their communities. Therefore, culture cannot use humans to shape itself and to transform the community. It is humans themselves who use culture to identify themselves and ultimately change their communities. Although the paper is theological in its approach, it argues for individual human rights to be respected and weighed above all cultural practices. It further concludes that such cultural practices are not static and that they can be removed from the rest of culture.

Intradisciplinary and/or interdisciplinary implications: This article, from a practical theological view, challenges the African cultural rituals that claim authority over women's rights and dignity. The interdisciplinary nature of this article indicates the sanctity of human individuals especially widows and thereby calls for paradigm shift to deconstruct certain oppressive teachings and practices against widows among African women. This article concludes thus, cultural deconstruction is possible.

\section{Introduction}

In the morning a day after the burial some elderly widows took me out to the forest with a chicken and egg, near a river where they performed more brutal rituals. They firstly killed and cooked that chicken. They tried to strangle off my secret hair with hands and forcefully moved out some painfully. When I cried they sang louder and louder so that people could not hear my crying voice. (Baloyi 2015:253-254)

These are the words of an informant in the article by Elijah Baloyi. The subject of women never ceases to intrigue us in all areas of human studies. The above quotation by Baloyi reminds us about an endless struggle for women's emancipation in all spheres of life, including some elements of cultural practices which are problematic. Baloyi (2015) indicates in his recent article entitled 'Woman-on-woman oppression: pastoral investigation into how African women oppress widows in time of grief' the horrific experience of a Tsonga woman who suffered at the hands of many other Tsonga women. He narrates the dilemma that widows face in the journey of widowhood and the mythological concepts that women construct with the aim of oppressing other women. The process of widowhood alone, as it is experienced in the bush (Baloyi 2015:253) is in itself problematic. Baloyi's informant (2015:254) indicates the severity and the problematic nature of the ritual performed on her by other women who went through the same process during their widowhood initiation. She indicates that the pieces of chicken served to her during the initiation process were marinated by dirty fluid taken forcefully from her genitals parts. This leaves one with a question of women's difficulties in reaching consensus on when and how to be critical of culture that continues to dehumanise them.

Although his research focused on the Tsonga widows, Baloyi indicates the extent of the problem even in other African tribes such as Venda and Sotho (Baloyi 2015:250), probably because they live in the same province. This indicates that widowhood rituals and practices are not confined to the Tsonga tribe. In all these areas, probably by virtue of their geographical locations, they share similarities which are severely inhumane towards widows.

In some communities of the Tsonga people, these practices have lately been carried out on those widows who are non-Christians, as opposed to the situation in the past. Widows who disrespect 
such cultural expectations are likely to be stigmatised, treated as if they have killed their husbands, and even ostracised from the community (cf. Miruka, Nathan \& Obongo 2015:240-250; Prah 2013:211). The most challenging situation for widows is the fear of being mocked and ridiculed by other women in public. Most widows undergo such rituals in order to be accepted as honourable women who respect the culture and the ancestors of that particular family or household. Most women who are Christian see no benefit in such practices, but that they have the effect of denigrating widows to a lower level. This creates a clash between culture, which is seen as the guiding tool to its people, Christianity and women's human rights. Many people believe that Christianity is not above African culture and that Christian widows should undergo such rituals. Although widowhood practices within the Tsonga tribe are closely tied to cultural and traditional beliefs, we cannot avoid its oppressive impact on widows. It is important to indicate that this reflection is not aimed at abolishing culture as such but to pin point those elements which continues to enslave widows in the name of pleasing ancestors and preserving culture.

\section{Other cultural practices against women's human rights}

Among cultural practices that continue to enslave women are issues pertaining to infertility. In some African societies, women have to go through sexual exploitation to conceal their husband's infertility by having sexual intercourse with their husband's relatives in order to conceive a child. When a married woman is found to be unfaithful or to have committed adultery, she is exploited, called names and subjected to divorce and other things that denigrate the very essence of her womanhood. This is in contrast to married men, who do not undergo similar treatment when they are found to have committed the same offences (see Oduyoye 2001; cf. Dyer et al. 2002:1664-1665).

Nonetheless, women remain the utmost gift to humanity and the world at large. They share a 'common human nature, characterized by reason and moral conscience' (Ruether 2002:87). This simply means one ought to be capable of acquiring moral ideas and of reasoning what is right and wrong beyond religious and cultural demands. Human dignity and equal rights in society emanate from 'reason and moral conscience' and should take precedence. While I acknowledge the patriarchal antagonism that exists against women by men in many levels or spheres, women are more often the perpetrators against other women in matters pertaining to cultural practices. Musimbi Kanyoro (in Ortega 1995:23) states that 'women must come of age, confront ourselves and also address women as the cause of oppression'. This of course is not a denial of all sorts of violence and abuse by males, but rather a way of indicating other areas of violence against women and a call to eliminate it. It is actually to ask for a critical approach to cultural practices that continue to degrade the whole essence of womanhood.
Kanyoro argues the need for women to use introspection and think more deeply about the realities faced by them. She states that this is not a refusal to address male oppression, but rather a way of empowering women to remove what she calls the 'log in our eyes so that we can see clearly the log in other people's eyes' (Kanyoro in Ortega 1995:23). This is why criticising the domination and oppression of women by men should not be viewed as the ultimate goal of women's freedom, but rather as a stepping stone in their development. Total freedom for women cannot be fully attained when inhumane cultural practices are still prevalent. Most cultural rituals release males from their control and leave only the women to suffer. Such cultural hegemonies should not be worshipped as if they have been prescribed by a higher authority and cannot be changed. Culture is dynamic, and as such is changeable!

\section{Culture and human dignity: What matters?}

The subjugation of women has many facets, ranging from sexuality, economics, politics and culture to religion in different societies. All human societies have their own cultural practices and beliefs, which direct a community on how they should conduct themselves. 'Culture is like a fabric which is woven and with many shades of colours. Some of which represent customs, practices and beliefs' (Wadesango, Rembe \& Chabaya 2011:121). Magnusson and Marecek (2012:20) argue that 'there is a fundamental recursivity of culture and humans'. They further state that culture cannot exist without human beings and human beings cannot exist without culture (Magnusson \& Marecek 2012:20). But this is not to suggest a blind tolerance of all aspects that create hardship for other human beings. Kalu comprehends culture as that part of the 'total repertoire of human action and its products, which is socially, as opposed to genetically, transmitted' (Kalu 2005:523; cf. Munro 1968). Kalu's understanding of culture as a repertoire and communally transmitted stands against the concept of culture as not an inborn or biological phenomenon, but a socially learned phenomenon.

Dreyer, in agreement with Kalu's view, states that people inherit the norms and ways of thinking of their society and internalise them. They become part of how people define themselves (Dreyer 2007:1516; cf. Haavind 2002:7-12). In agreeing with Kalu and Dreyer, one may be correct in saying that culture poses a set of meanings that humans themselves have produced and incessantly re-create. All negative aspects that complement culture are unconsciously entrenched not only in the community but also in people's lives. However, any cultural system that dehumanises and marginalises a human individual, especially women, can be amended or removed. Susan Rakoczy, in Maluleke and Nadar (2002:14), also indicates that 'while cultural norms and values are very important in our lives, they are not absolute'. The fact that 'cultures are not static' (Maluleke \& Nadar 2002:14) signifies that parts of them can be removed without people being 
affected. On the basis of the above, it is my view that culture without people cannot exist. Furthermore, it cannot even exist in isolation or even in a void.

For culture to exist, it must depend solely on the existence or presence of human beings and their communities. It finds its absolute meaning and identity where there are human beings. If culture were to exist without people, it would have no identity because there would be no people to whom it belongs and by whom it is shaped. Therefore, culture cannot use humans to shape itself and to transform the community: but humans themselves use culture to identify themselves and ultimately change their communities. It is in this regard that people learn about culture and transmit it to the next generation within the society. What this suggests, perhaps, is that as such education is carried out by people, it can also be changed by people. Chielozona (2015:310-311) argues that 'individuals within a particular culture have the right to question that culture particularly in regard to their human rights and dignities'. As culture is socially constructed and performative, the meanings of its categories and the values attached to them are human-made. Therefore, deconstructing part of it that makes women feel powerless cannot be a violation of anybody's rights. Instead, itis anacknowledgement that as culture is not absolute and does not exist in any inherent biological feature, so modification is possible.

I take into account that cultural rituals and initiation practices are one area in which it may be difficult for women to reach consensus. Nonetheless, one must find a good balance that is neither abusive nor demeaning to other humans. Most culturally defined roles and rituals are a means to hinder women from personal development in many areas, including the institution of marriage, businesses, leadership positions, the priesthood, et cetera (see Prah 2013:30-39; cf. Kanyoro 2002:18-19). In widowhood, I believe they are a means to control women's bodies and limit their individual rights and movements. Feminists have advocated the rights of women to freedom over their bodies and their sexuality, including matters pertaining to cultural rituals (see Kanyoro 2002; Ruether 2002:78-97; Waruta \& Kinoti 2013:120-153).

Mwambene (2010:81) reminds us of the provision of Article 27(1) of the Universal Declaration of Human Rights, which states that 'everyone has the right to freely participate in a cultural life of the community'. It is indecorous to take the status of women and place them under the heading of 'culture' and begin to define and demarcate their movements. Mwambene (2010:84) goes on to indicate the promulgation of the Protocol of the African Union's (AU) concern that 'women in Africa continue to be victims of discrimination and harmful cultural practices'. The Protocol prohibits 'all forms of harmful practices that negatively affect the human rights of women and which are contrary to recognised international standards' (Mwambene 2010:84; see Article 5 of the Protocol [Viljoen 2009]). Although Mwambene writes from a legal, and not theological, perspective, human rights issues have no boundaries in terms of their relevance. Matters of human rights will always be important wherever there are human individuals.
The above articles on protection of women's rights serve as a benchmark to ensure adequate protection for women in Africa (see Geldenhuys et al. 2014:683). During the fourth World Conference on Women in Beijing 1995, Hillary Clinton argued that 'women will never gain full dignity until their human rights are respected and protected' (Witte \& Alexander 2012:303). We are in agreement with Clinton that human rights issues cannot be discussed anywhere separately from women's rights. Women constitute what it truly means to be human and their rights must be discussed as part of humanity. But Maluleke and Nadar remind us that 'violence against women will not and cannot be combated merely and only by pieces of government legislation' (Maluleke \& Nadar 2002:15). This means that fighting violence against women should be a matter of actions more than words. Even when women can organise themselves to fight against this struggle, it still needs a collective effort. Ackerman points out that 'we (often) find it easier to talk about changing circumstance than to address the equally fundamental need to change our attitudes and our behaviour' (Ackerman 1996:15). Ackerman is correct and I agree with him; change starts from oneself and ultimately transfers to the other person. Although change involves using many psychological mechanisms to free oneself from many attitudes and behaviours, it is nevertheless required. However, one should not overemphasise the negative impact of culture on women or fail to acknowledge the many positive values that contribute to the goodness of African culture (see Kyalo 2012:211-219).

\section{Being human (male $\&$ female) is to be free}

In theology, we believe the question of human beings dates back to the Bible and the creation story. The theologian Karl Barth once asked: 'what sort of house is it to which the Bible is the door? What sort of country is spread before our eyes when we throw the Bible open?' (Barth 1957:28). Barth's response to his own question was that one enters a 'strange world'. The first section of scripture endorses what Barth calls a 'strange world' with the creation of human beings and the entire environment. Both creation accounts in Genesis 1:2 assert quite categorically that human beings are the pinnacle, the climax, of the divine creative activity; if not climactic, then central or crucial in the creative activity (McGrath 2011:348-349; Witte \& Alexander 2012:1). In the first version, the whole process moves impressively to its climax, which is the creation of human beings. By divine fiat, something came into being ex nihilo (see Witte \& Alexander 2012:1). This means that the act of creation is creatio ex nihilo and thus totally free. Therefore, there is no obligation, ontological or normative, in God's resolution to create. The climactic creation of human beings stresses the significance of the individual's worth before God. According to McGrath (2011:348-359): 'theological justification of this rests largely upon the doctrine of creation in the image of God'.

Some Jewish exegetes have argued that God created humanity in the image of the angels, interpreting the context 
of Genesis 1:27 to imply that God's words were addressed to an angelic audience. Others argue that 'the text was to be interpreted as implying that humanity was created according to some image that was specific to it, thus distinguishing humanity from the remainder of creation' (McGrath 2011). But for Jürgen Moltmann, to be created in God's image is thus not simply or primarily to be god-like, analogically, but rather to be set in an especially close relationship to God and in particular, given the task of representing God in creation. Insofar as humans are defined by this relationship, it cannot be evaded or destroyed, not even by gender attribution: the imago Dei and with it, 'the dignity of human beings is unforfeitable, irrelinquishable, and indestructible' (Moltmann 1993:233). I agree with Moltmann; it seems implausible that God would create a woman without value and subsequently declare her not equivalent to human. The fact that God is goodness himself is an indication that he would not contradict his goodness by creating something less good. It further indicates that, from the creation story, human beings take precedence over everything that is designed including a culture that is sociological. This point of departure impels us to place 'priority on the welfare, worth, and dignity of human beings' (Gordon 2008:186). No amount of reasoning can justify violating the dignity of other human beings, especially women. Deeper reverence for the sacredness of human life lies not only in religion but also in how we connect with other human individuals in all spheres of life. We know that God could not have created a being that appears to be feeble and susceptible to denigration (cf. Stevens 2011:21-22). Even though the aspects of culture relating to widowhood rituals have long been seen as an 'integral' part of the lives of most African women, this does not mean they have superiority over the life of every human, which is an uninfringeable gift from God. As a result, to treat another human being as worthless and even to trample their dignity underfoot is not just problematic, it is also blasphemous (cf. Witte \& Alexander 2012:1-4) as Desmond Tutu stated. According to Coll (1994):

when the systems operative in a culture are demeaning and dehumanising, a vicious circle is set in motion in which women ... are prevented from developing the full humanity to which they are called. (p. 84)

It is imperative to note also that 'fractured humanity is incapable of creating a society that is truly human'. A healthy society cannot be fully created when women remain 'object[s] of ridicule and negative spontaneous associations' (Stevens 201101:22). McGrath states that the image of God is understood to be the human rational faculty, which here mirrors the image of God' (Stevens 2011:441). He goes further to substantiate this by stating Augustine's argument that:

it is this faculty which distinguishes humanity from the animal kingdom: we ought therefore to cultivate in ourselves the faculty through which we are superior to the beasts, and to reshape it in some way. (McGrath 2001:441)

In agreement with McGrath, one has to use one's intellect to judge one's own behaviour towards the rest of creation, including humanity itself. Although Augustine here does not use a theological premise to justify the human exploitation of animals, his point is that the central distinctive element of human nature is its God-given ability to relate to God (see McGrath 2011:348-349). Therefore, this places attributes such as rationality, freedom and moral agency above personal and cultural demands over other human individuals.

\section{Paradigm shift}

Cultural widowhood rituals clash head on with the rights of individuals involved in the act. Despite the widow's tears, many African women continue to instigate this practice even when it threatens someone's life. A culture that disregards one side of human individual rights but promotes the other fails to acknowledge what it means for God to have created a human being as complete. It fails to recognise that human individual rights are essential steps towards reaching full development for women. A well-balanced and fair culture would expect both men and women to practise the same cultural rituals. Women are told to be quiet and obedient in all matters relating to their marriage and womanhood, for that is what it means to be a woman (cf. Baloyi 2015:253-254; Maluleke \& Nadar 2002:11). This is contrary to the treatment men receive in similar circumstances such as death. This is why Oyeniyi and Ayodeji argue that our societies have always put men first, by feeling sorry for them and being careless about how women feel (see Oyeniyi \& Ayodeji 2010). Ramphele also indicates that widowers are given much encouragement to move forward and forget about the past (Ramphele 1996:100). If a man becomes a widower, who does he forget before he moves forward? Is it not a woman?

It is clear that other cultural rituals are unjust and aim to denigrate the essence of womanhood. If cultural practices are there for people, they should be for all human individuals residing in that particular community. But if they are aimed at one category of humans, then these practices are unjust to others and therefore must be removed. Inasmuch as culture matters, it must fall within the parameters of individual rights. It cannot be fair that certain cultural practices are protected and promoted as part of a heritage while humans themselves are suffering under them. It is for this reason that our theology must aim at the humanness of humanity, irrespective of culture. African women and widows need a future in which both women and men as humans are friends to rework culture together. Building that future does not begin by attacking each other, but by reasoning together to find a suitable method of bringing about change for all individuals. As we have observed above, many African women find it difficult to reason with others to condemn a culture that allows evil to enter women's lives. Our argument is mainly against those who are loyal to cultural rituals that enslave other women. Kanyoro in Ortega (1995), speaking from the Biblical point of view in search of cultural hermeneutics, indicates that:

our concern with Biblical text is not just to condemn the culture but to seek tools to analyse culture in order to reach out to women who are in bondage to it. (p. 22) 
In agreement with Kanyoro, such tools must include awareness of those who continue to practise widowhood rituals as part of their cultural heritage.

\section{Conclusion}

An unfree human being is a contradiction in terms. To be human is to be free at all levels. Human beings have autonomy and integrity that should not be violated or even subverted (Witte \& Alexander 2012:4). Witte and Alexander go further to state that we are created to exist in a delicate network of interdependence with fellow human beings and the rest of God's creation (Witte \& Alexander 2012:4). But interdependency is possible in a healthy environment for all human beings. A society that has elements of hostility in its cultural practices cannot promote this interdependency. For human individuals to be interdependent there has to be an element of understanding of the fundamental principles of what it means to be a woman and a man as part of humanity. Therefore, I believe that the complete humanity of women is essential, regardless of colour or even geographical location. The most fundamental challenge for the future is 'raising awareness not only in elderly women but to the young girls also, about the value and virtue of being a woman in a society' (see Charmaine, Pillay \& Dunbar-Krige 2015:472). Although 'value' is such a broad notion that also touches the whole ethical value of art, it does not negate the value of the human individual, which supersedes all. It reflects what most theologians (Moltmann 1993:233; McGrath 2001, 2011:348-349) call God's 'climatic creation' in the Genesis story. Although culture is ingrained in our societies, the value attached to individual human beings ought to be respected at all costs.

\section{Acknowledgements Competing interests}

The author declares that he has no financial or personal relationships that may have inappropriately influenced him in writing this article.

\section{References}

Ackerman, D., 1996, 'For such a thing is not done in Israel: Violence against women' in L. Hulley, L. Kretzschmar \& L.L. Pato (eds.), Archbishop Tutu - Prophetic witness in South Africa, pp. 145-55, Human \& Rousseau, Cape Town.

Baloyi, E., 2015, 'Women on women oppression: Pastoral investigation into how African women oppress widows in time of grief', in F.H. Chimhanda, V.M.S. Molob \& I.D. Mothoagae (eds.), African theological reflection: Critical voices on liberation leadership, gender and eco-justice, pp. 247-270, BB Service, Unisa, Pretoria.

Barth, K., 1957, 'The strange new world within the Bible', in D. Horton (ed.), The Word of God and Word of man, pp. 28-50, Harper \& Brothers, New York.
Charmaine, L., Pillay, J. \& Dunbar-Krige, H., 2015, 'Patriarchal influences on the lives of African adolescent girls from child-headed households', Journal of Psychology in Africa 25(5), 470-472. https://doi.org/10.1080/00020184.2015.1067996

Chielozona, E., 2015, 'Feminist empathy: Unsettling African cultural norms', in The Secret Lives of Baba Segi's Wives, African Studies 74(3), 310-326.

Coll, R.A., 1994, Christianity and feminist in conversation, Twenty-Third Publishers, Mystic, CT.

Dreyer, Y., 2007, 'Karl Barth's male-female order as asymmetrical theoethics', HTS 63(4), 1493-1512. https://doi.org/10.4102/hts.v63i4.265

Dyer, S.J., Abrahams, N., Hoffman, M. \& Van der Spuy Z.M., 2002, 'Men leave me as I cannot have children': Women's experiences with involuntary childlessness', Human Reproduction 17(6), 1663-1668. https://doi.org/10.1093/humrep/17.6. 1663

Geldenhuys, M., Kaufulu-Kumwenda, C., Nabaneh, S. \& Stefiszyn, K., 2014, 'The African Women's Protocol and HIV: Delineating the African Commission's general comment on Articles 14(1)(d) and (e) of the Protocol', AHRL J 14, 681-704.

Gordon, L.R., 2008, An introduction to African philosophy, Cambridge University Press, New York.

Haavind, H., 2002, Kulturpsykologi, Bevegelser I livsløp [Cultural psychology narratives through the lifespan], Scandinavian University Press, Oslo.

Kalu, O., 2005, African Christianity: An African story, series 5: vol. 3, Business Print Centre, Pretoria.

Kanyoro, M., 2002, Introducing feminist cultural hermeneutics: An African perspective, Sheffield Academic Press, London.

Kyalo, P., 2012, 'A reflection on the African traditional values of marriage and sexuality', International Journal of Academic Research in Progressive Education and Development 1(2), 211-219.

Magnusson, E. \& Marecek, J., 2012, Gender and culture in psychology: Theories and practices, Cambridge University Press, New York.

Maluleke, T.S. \& Nadar, S., 2002, 'Breaking the covenant of violence against women', Journal of Theology for Southern Africa 114, 5-17.

McGrath, A.E., 2001, Christian Theology: An introduction, Blackwell, United States.

McGrath, A.E., 2011, Christian Theology: An introduction, 5th edn., Blackwell, London.

Miruka, P., Nathan, J. \& Obongo, J., 2015, 'The Cultural view of the Luo People of Western (Kenya) on Widow Care and the Biblical Approach', Sociology and Anthropology 3(4), 240-250. https://doi.org/10.13189/sa.2015.030405

Moltmann, J., 1993, God in creation, The Gifford lectures 1984-1985, transl. M. Kahl, Fortress Press, Minneapolis, MN.

Munro, H.D., 1968, 'Culture', in G.D. Mitchell (ed.), A dictionary of sociology, Routledge \& Kegan Paul, London.

Mwambene, L., 2010, 'Marriage under African customary law in the face of the Bill of Rights and international human rights standards in Malawi', African Human Rights Law Journal 10(12), 78-104.

Oduyoye, M.A., 2001, African women's theology, The Pilgrim Press, Cleveland, $\mathrm{OH}$.

Ortega, O., 1995, Women's vision: Theological reflection, celebration, action, WCC Publication, Geneva.

Oyeniyi, A.J. \& Ayodeji, I.G.E., 2010, 'Widowhood practices among the Yoruba of south-west Nigeria: Are there differences in what women experience due to their status?', Gender and Behaviour 8(2), 3152-3166.

Prah, M., 2013, Insights into gender equity, equality and power relations in SubSaharan Africa, Fountain Publishers, Kampala.

Ramphele, M., 1996, 'Political widowhood in South Africa: The embodiment of ambiguity', American Academy of Arts and Sciences 125(1), 99-117.

Ruether, R., 2002, Sexism and God-Talk, SCM Press, Britain.

Stevens, F.L., 2011, The African philosophy of self-destruction, 3dp New Media, Pinetown, RSA.

Viljoen, J., 2009, 'An introduction to the protocol to the African Charter on human and peoples' rights on the Rights of Women in Africa', Washington and Lee, Journal of Civil Rights and Social Justice 16(1), 11-46.

Wadesango, N., Rembe, S. \& Chabaya, O., 2011, 'Violation of women's rights by harmful traditional practices', Anthropologist 13(2), 121-129.

Waruta, D.W. \& Kinoti, H.W., 2013, Pastoral care in African Christianity: Challenging essays in pastoral theology, 3rd edn., Acton Press, Nairobi.

Witte, J., Jr. \& Alexander, F.S., 2012, Christianity and human rights: An introduction, Cambridge University Press, New York. 